Rev. Przemystaw Artemiuk

Cardinal Stefan Wyszyński University in Warsaw, Department of Theology

\title{
The New Apologia: A Definition and Its Characteristics ${ }^{1}$
}

The current form of apologia, which those within the milieu of the Department of Fundamental Theology and Philosophy at the Cardinal Stefan Wyszyński University in Warsaw have termed the "new apologia," is a contemporary and extremely dynamic phenomenon that has been developing in a multifaceted way since the end of the twentieth century to the present time. The new apologia's dynamic return dates back to 1990s and the particular characteristics of this type of defense include: engagement, timeliness, insight, a constant presence in the sphere of the media, originality of arguments, and intellectual achievements. The new apologia "occurs" on many levels today, but most notably in contentious areas such as man's identity as it is expressed in subjectivity, historical memory, culture, rationality and bioethics, and, above all, the Christian faith, which has been subjected to various trends that intend to deconstruct it: anthropological reductionism, Christophobia, jihadism, secularization, secularism, and alethophobia.

Key words: apologia, new apologia, apologetics, fundamental theology.

\section{Introduction: The Context of Apologia's Return}

After years of absence, apologia has returned ${ }^{2}$. Although apologetic sensitivity was set aside during the post-conciliar period and dialogue seemed to pervade the Church, we have witnessed the return

In the text I cite passages from my book: The Renaissance of Apologia, Plock 2016.

2 See Return of Apologia, ed.M. Skierkowski, Płock2013; H. Seweryniak, "Apologia and the New Evangelization," Communio 185/2014, pgs. 5-20; ibid., Apologetic and Journalistic Writings, Plock 2016; ibid., Apologia and Journalism, Warsaw 2018. 
Fundamental Theology

of apologia with the expansion of the New Leftist ideology since the end of the twentieth century. Contemporary apologia, however, does not imitate old forms of apologetics; rather, it has taken on a different form, which is referred to as the "new apologia." When defining what, precisely, this expression means, it is necessary to consider the context from which the new apologia arose, the apologists who practice it, the subjects that it addresses, the apologists who practice it, and the tools and language they use to do so. ${ }^{3}$

The new apologia take place within the context of our current time and space - a fluid and muddled post-modern world that deconstructs basic concepts and is dominated by the dictatorship of political correctness. The postmodern world asserts that there is no God and that dusk of christianitas has descended. It has abandoned metaphysics and proclaims the triumph of ambiguity. This world is also wearied by its lack of ideological orientation and longs to return to lasting values. Yet, it cannot abandon the darkness and open itself up to the light because it has lost its faith in transcendent truth and distrusts all religions, which it often identifies with fundamentalism and violence.

\section{A Definition of the New Apologia}

The context of the new apologia decisively influences and shapes its object. Traditionally, apologia is defined as a defense of the Christian faith and its values. Based on recent studies, however, this definition is insufficient. When considering the entire subject of the new apologia, one must broaden his point of view and see that apologetics has a much earlier beginning, within the civilization itself, and man is its first sphere. Modern apologia is, therefore, a defense of human identity, which is expressed in man's historical memory, his responsibility for his own actions, the inviolability of life, and a culture that manifests a second-spiritual—dimension. In addition to defending humankind, the objective of apologia is naturally defending Christianity itself and its presence in the world. The new apologia fights for the Christian soul, justifies the existence of evangelical Catholicism, demonstrates

3 See A. Bielat, Save Europe: Henryk Sienkiewicz - A Christian Apologist and Defender of Latin Civilization, Sandomierz 2012; S. Puchaczewski, The Witness of a Miracle at the Cathedral of Paris: The Apologia of André Frossard's Faith, Plock 2009; R. L. Puttill, In Defense of Faith: C. S. Lewis' Arguments for Christianity, trans. J. Urbanek, Poznan 2013; K. Stępniak, In Search of the Ideal Church: The Life and Work of Tadeusz Żychiewicz (1922-1994), Olecko 2004; S. Zatwardnicki, Imaginary Atheism: A Christian Response to the Negation of God, Cracow 2013. 
the rationality of Christianity, and seeks space for pre-evangelization. Finally, the new apologia defends the essential contents of the faith and refutes arguments that strike at the heart of Christianity.

Synthetically speaking, the aim of a new apologia is to rescue man by defending his identity and the meaning of the presence of Christianity in the world and refuting allegations against the Christian faith by presenting arguments in favor of it. In carrying out its mission, the new apologia extends far beyond the typical religious sphere and moves freely in "secular" reality. In this way, is a broader over-confessional or even non-confessional trend that, nevertheless, regards Catholicism as its source, life-giving foundation that appears within the scope of justification. The main and unchanging task of the new apologia is to defend the supernatural character of Christian Revelation within the current context while clearly understanding this context. In carrying out its mission, apologia formulates responses to the objections raised from outside (apologia ad extra) and seeks out the arguments that are essential to making one's certainty of faith firmer (apologia ad intra).

The new apologia is a practical and intellectual defense. Those who engage in it are a large group of apologists. ${ }^{4}$ The contemporary context, meaning the postmodern world, is imbued with a polemical and anti-Christian spirit that necessitates apologists to defend the faith. Therefore, we are witnessing a very interesting phenomenon-namely, many talents in the field of apologetics are coming forward. Among these talents are not only outstanding intellectuals but also whole communities such as Christianitas, First Things, Fronda, and Political Theology. The scope of their activity is very broad and varied, they adapt their tools to current conditions, and they use language that is flexible and suitable to the sensibility of their recipients. So scientific works as well as different kinds of publications (articles, interviews, feature articles, reviews) are among the new forms of apologia. The lecture hall, university department, and church pulpit are not the only

The creators of the new apologia include R. Alberoni, P. Badde, W. Chrostowski, G. Górny, M. Hesemann, A. Horubała, M. Jurek, D. Karłowicz, K. Koehler, Z. Krasnodębski, and J. Kudasiewicz, R. Legutko, P. Lisicki, P. Milcarek, R.J. Neuhaus, A. Nowak, D. Oko, J. Pospieszalski, J. Ratzinger, J. Salij, P. Seewald, P. Semka, A. Socci, T.P. Terlikowski, G. Weigel, W. Wencel, B. Wildstein, S. Zatwardnicki, R. Ziemkiewicz, and M. Zięba. The thought of B. Pascal, J. H. Newman, G. K. Chesterton served as a precursor to the new apologia. Those whose thought was at the forefront of the new apologia's return in the 1990s were A. Frossard, T. Żychiewicz, V. Messori. This new kind of apologetics is characterized by a commitment to defending the foundations of Christianity and Christian civilization, timeliness, deep insight, a constant presence in the sphere of the media, the originality of its argument, and the intellectual achievements. 
place for apologetic rhetoric, so too are discussions, debates, polemics, protests, events, and demonstrations. Therefore, the new apologia is present wherever the truth and sense must be defended and justified.

Fundamental

Theology From the Warsaw School of Apologetics to the New Apologia

Since the late 1950s, the former Warsaw School of Apologetics (which has existed since the Joint Chair of Apologetics of the Department of Theology of the Academy of Catholic was established on January 1, 1956) has systematically reflected on apologia according to its own methodology. It sought to scientifically justify the veracity of Catholicism's claims and offer a critical assessment of its apologia. ${ }^{5}$ Assuming a religious point of view when examining Christian apologetics, total apologetics (so termed by W. Kwiatkowski, d. 1972) focused on the axiological or normative value-namely, the presence of the sanctum in Jesus of Nazareth's consciousness and activity, ${ }^{6}$ meaning "the oldest classical system of apologetics originating from Jesus Himself." At the same time, total apologetics pointed out that Christianity brings together all values to the highest degree, which determines its absolute normative character. W. Kwiatkowski's project culminated in the creation of apologetics as its own independent scientific field that resembles theology and religious studies ${ }^{8}$.

While referring to studies conducted by the Warsaw School of Apologetics, I continue to reflect on the contemporary apologetic reality and am convinced that the present form of apologia, which the fundamental theology milieu of the Cardinal Stefan Wyszyński University calls the "new apologia," is an extremely dynamic phenomenon that has developed in a multifaceted way since the end of the twentieth century and deserves attention and comprehensive analysis.

$5 \quad$ See I. S. Ledwoń, "Apologetyka," in: Lexicon of Fundamental Theology, edited by M. Rusecki, K. Kaucha, I. S. Ledwoń, J. Mastej, Lublin-Cracow 2002, pgs. 78-85.

$6 \quad$ In other words, W. Kwiatkowski emphasizes that, according to an empirical approach, total apologetics is critical and systematic cognition, and from an axiological point of view, it is guided by Jesus Christ's defense of Himself as the highest religious value (Sanctum)." See W. Kwiatowski, Total Apologetics, vol. I, Warsaw 1961, p. 153. Apologetics," Studia Theologica Varsaviensia 3/1965 No. 1, p. 6. 


\section{Research}

My view of apologetics differs in its perspective, scope of research, and methodology from the view upheld by former Warsaw apologists. As a fundamental theologian who deals with the "the factuality, meaning, and signs of the credibility of the saving revelation of God Fundamental in Jesus Christ and its representation in the mystery and community of the Church," I have a great deal of respect for my predecessors. I do not, however, accept their methodology which draws on religious and pre-theological studies. Classical apologetics, which influenced the sixteenth to the nineteenth centuries and maintained a polemical approach towards the Enlightenment, developed rational arguments in favor of Christianity. Since classical apologetics regarded the positivist model of science as ideal, it rationalized its own mode of argumentation. By creating objective criteria, classical apologetics was tempted to remain extrinsic and, as a result, did reflection deeply on Revelation. ${ }^{10} \mathrm{I}$, therefore, will analyze the new apologia from the perspective of fundamental theology because I want to look at this reality with reason enlightened by faith.

Their scope of research and the methodology are that which further differentiate the perspectives of fundamental theology and apologetics. When researching the new apologia, I do not limit myself only to the person of Jesus and His apologetic system (note that this was the foundation of total apologetics). Instead, I want to show as thoroughly as possible what the new apologia is or, rather, what its commitment to defending the values that shaped Euro-Atlantic civilization and that are now threatened looks like.

\section{The Characteristics of the New Apologia ${ }^{11}$}

1. Contextuality. The new apology takes place in current space and time. Therefore, the ability to perceive and understand the context of Christianity within this context is essential if the new apologists are to effectively defend it. Modern apologists are able to accurately discern the spirit of the times in prominent ideas and intellectual trends. They pay special attention to any activity that is openly or secretly antiChristian, and they oppose the dictatorship of political correctness that is often endemic in the activities of institutions that impose the

H. Seweryniak, Fundamental Theology, vol. I, Warsaw 2010, p. 52.

See Ibid, pp. 26-30.

See P. Artemiuk, The Renaissance of Apologia, pgs. 542-548. 
Fundamental Theology

will of the secular minority. Refusing to allow basic Christian concepts and values to be deconstructed, they defend them and substantiate Christianity's superiority over postmodern philosophy. Apologists also point to Christianity's tenacity and immutability, which its enemies strive to discredit or confuse. The creators of the new apologia recognize how far-reaching secularization, which is evident in countries that attempt to build societies without God and are devoid of any references to Christianity, has become and see salvation for a world that has rejected the sacrum in the living community of faith.

2. Over-confessionality or non-confessionality indicates that the new apologia takes place within completely secular space. When defending fundamental principles, modern apologists side in favor of common sense, truth, honesty, and justice. They treat Catholicism as their natural foundation as well as the foundation on which all of civilization is built. For this reason, they continue to refer to it. Christian values always appear when it is necessary to justify Catholicism.

3. Dialogicality. Although apologia has returned partly because dialogue had been exhausted, it does not mean that the new apologia completely rules out a dialogic approach. On the contrary, dialogicality is present in many dimensions of contemporary apologia. First, it appears in the apologetic method itself in the form of curiosity, a desire to learn, openness, and interest in the world. New apologists emerged as creators who are well oriented in postmodernity. They move freely in different areas of culture. Their conservatism has nothing in common with the closing themselves off or hiding in the "silence of the cloister;" rather, it is the resounding voice of defense in the hustle and bustle of this world. Reality does not scare new apologists, nor do they see it as the realm of the forces of evil; this is why they do not shut reality out to maintain integrity. They search for traces of God in the world and point out the existence of an interior logos, according to which man can order created reality. They avoid "either, or" exclusions such as: either dialogue or apologia. Their aim is not to either defend or dialogue only. To them, the new apologia is "apologia in dialogue."

4. Sacramentality means referring to symbols and restoring their rightful place by showing how they are both timely and timeless. Apologists point out the amnesia that is characteristic of the present times as well as the existence and importance of memory. Thanks to the new apologists, man returns to symbols and rediscovers their dynamics. Symbols, which give food for thought, serve as reminders that making a radical break from the past is disastrous. 
5. Veracity. The new apologia reveals the quest for truth in two ways. First, the new apologists look to the native past. For the new apologists, the imperative of truth is a necessary requisite for fostering accountability. Only by taking an account of the past, coming out from its shadows, and submitting ourselves to the purifying action of veritatis splendor will Poles freely look at their experience of being under communist captivity, and, at the same time, uncover the deformed face of democracy and the dangerous European wilderness, all of which are full of false postmodern ways. The veracity of apologia can also reveal the entirely new ideology that is emerging from the European discourse that the new apologists call alethophobia. Alethophobia is not only a fear of the truth itself but also an ideology that combines old strategies such as using Enlightenment clichés and political correctness to fight against all manifestations of religion, particularly Christianity, but especially Catholicism. Paradoxically, as an ideology, alethophonia goes against the ideological inclinations of religion and simultaneously seeks to create a new man, free from all ties to God and to others. In its defense of the truth, the new apologia reveals both the need for truth in the context of developing responsibility and man's fear of it, which is evident in postmodern liberalism and alethophobia.

6. Rationality. The defense of reason has a special place in the new apologia. Apologists defend rationality because they perceive it as a constitutive element of human identity, which fundamentally shapes man. By defending and emphasizing reason, new apologists not only oppose irrationality or fideism, but also show that man capable of discovering the phenomenon of his existence, his depth, and his finiteness. As Pascal states, it is thanks to reason that man can perceive both his greatness and his misery. The rationality of existence forces apologists to defend the gift of life from conception to natural death. For, it is reason that makes man ask fundamental questions and search the depths, which is God. In defending rationality, the creators of a new apologia see reason as constantly present in Christianity.

7. Depth of culture. When critically analyzing works, many modern apologists not only evaluate their objective value, merits, artistry, or innovative forms, but, and above all, seek to find what is at their depths, which they hope will point out and direct them to other areas of human existence. For many of today's apologists, reflecting on culture is a path of discovery-a journey to the source itself. Within culture, the new apologia preserves the tradition of the masters and reveals the superficiality of outwardly refined authorities on culture and the spiritual emptiness of their artistic forms. The new apologia 
Fundamental

has determined that its role is to reveal other dimensions in order to defend culture against becoming entangled in ideologies. The apologia of culture, therefore, strives to unveil to man the Beauty contained within the cathedral and in man's pilgrimage to the source.

8. Defending the Church is an essential in the arena in which many of today's modern apologists go to battle. This defense is not isolated from the ecclesial community; rather, it is at its heart. The Church is, firstly, the source of man's experience of faith, the place of his spiritual growth, and the space in which he encounters God and his neighbor. This is the Church that apologists defend and that guides their activities. Defending the Church is first form of apologia ad intra, which is a particular approach to apologetics that simultaneously justifies and presents to others the interior of ecclesial structures. The new apologia involves apologia ad extra, which means defending the Church against accusations aimed at it from the outside. The ability to identify and recognize these two types of apologetics is essential before apologists can establish their own lines of reasoning. From there, they can formulate their defense in order to point out and refute a variety of anti-Christian arguments. Listening to different objections, they defend pillars of the Church such as Catholic anthropology, bioethics, rationality, and the historicity of Jesus.

9. Power of paradox. Today as in ancient times, apologists often refer to paradox when substantiating Christianity. The Christian attitude toward the world is very clearly paradoxical not so much in the ways in which it presents itself, but because "Christianity is not an object that we can hold in our hands; it is a mystery in relation to which we remain eternally ignorant and sacrilegious." This is why so many Christians do not so much as adapt to the world as they enter into it with a particular agenda that is influenced by Jesus' teaching. The Person of Christ and the fact that He came to earth-the Incarnation-is the greatest paradox of faith. The greatest paradox of Christianity is most clearly manifested in the fact that Christianity itself still exists and that no one has managed to destroy it thus far, not even Christians who are too often indifferent to Jesus' words. The Christian faith is founded on a paradox, and the fact that Christians exist is also paradoxical. The presence of the Christian faith in the world today is nothing but manifestation of its paradoxicality.

10. Defending Jesus is an important feature of the new apologia. At first, the figure of the Master of Nazareth appears indirectly on the horizon of apologetics. In seeking the truth, apologists come to Jesus who alone is the Highest Truth. When reflecting on someone who gave 
witness with his life, the new apologists first recall Socrates, since he remained faithful to his own convictions to his death, and then Christ, who sacrificed Himself for the salvation of everyone. When defending the inviolability of human life, they turn ultimately to Jesus' words, which confirm their intuitions. The creators of the new apologia do not substantiate only Jesus' teaching; rather, they directly defend His Person. To substantiate Christ's identity, their arguments draw on archeology, spirituality, anti-ideology, history, and theology. Apologists point to the historicity of Jesus and His divine dignity, and, rejecting ideological clichés that date back to the Enlightenment, they argue that the Master of Nazareth is invariably a reliable Teacher and Spiritual Guide who man can follow and to whom he can entrust his life.

11. Martyrdom. Although martyrdom is not always an integral part of the new apologia, martyrs are those who give witness with their lives in defense of the truth. It is a known fact that the most effective defense of Christianity is made only by a true witness-someone who is sensitive to contemporary challenges, attached to Christian tradition, and enlightened by and living the faith. This [kind of witness] makes God credible in the postmodern world. A witness is someone who is faithful to the end, penetrating, insightful, well-rooted, does not shy away from the consequences of his attitude, supports his arguments with well thought-out analyses, perseveres on the path he has chosen, and draws his strength from his inner depths. Modern apologists are both guardians, ready to defend fundamental values, and civilization, the source of which is Christianity, as well as witnesses to the truth, which comes from God. They share an abundance of personal beliefs and testimonies about the decisive moments that clearly impacted their lives. They define these as moments of conversion, reversion, or an encounter with God. For many, this experience becomes the leitmotif of their apologetic mission. Being an apologist is an intellectual task that involves determining the reasoning behind Christianity and speaking the truth and adhering to it. Being an apologist also entails having a particular approach to the world that entails being a witness according to a broad understanding of the word.

\section{Bibliography:}

1. Artemiuk, P., Renesans apologii, Plock 2016.

2. Kwiatkowski, W., Apologetyka totalna, Vol. I, Warsaw 1961.

3. Kwiatkowski, W., Apologetyka totalna, Vol. II, Warsaw 1962.

4. Kwiatkowski, W., "Początki i rozwój Warszawskiej Szkoły Apologetycznej," Studia Theologica Varsaviensia 3/1965 no. 1, pgs. 5-18. 
5. Ledwoń, I. S., "Apologetyka," in: Leksykon teologii fundamentalnej, ed. M. Rusecki, K. Kaucha, I. S. Ledwoń, J. Mastej, Lublin-Cracow 2002, pgs. 78-85.

6. Skierkowski, M, Ed., Powracanie apologii, Plock 2013.

Fundamental 7. Seweryniak, H., Teologia fundamentalna, Vol. I, Warsaw 2010.

Theology 8. Seweryniak, H., "Apologia i nowa ewangelizacja," Communio 185/2014, s. $5-20$.

9. Seweryniak, H., Skrypt $z$ apologii i dziennikarstwa, Plock 2016.

10. Seweryniak, H., Apologia i dziennikarstwo, Warsaw 2018. 